\title{
Organizational Culture Mediate Between E-Commerce Adoption and Hotel Performance
}

\author{
A.H. Mutia Sobihah
}

Doi:10.5901/mjss.2015.v6n2p61

Lukman Z.M.

\section{Abstract}

Global organizations can go on the information highway and dramatically improve the way business interactions by using Ecommerce. This situation and demands force each organization to change, to abridge the gap in environmental changes that take place. One of those who get the full benefits of E-commerce is the hotel industry. The full potential of values brought about by E-commerce in Malaysia is unable to realize. This paper shows the role of organizational culture among E-commerce adoption and hotel performance in Malaysia, from a survey of 111 hotels, four (4) stars above, and 146 hotels three (3) stars below as a sample. Based on the conceptual framework, it can be hypothesized that Organizational culture positively mediates the effect of E-commerce adoption on hotel performance. A statistical Package for Social Science (SPSS) Version 20 was used to examine the data. Pearson correlation analysis and descriptive statistics were performed to determine the collinearity problem, and to analyze the relationship between the variables. Lastly, multiple regression analysis was recommended to assess the mediating variable in the relationship between independent variable and dependent variable (Baron and Kenny, 1986). The final results of Pearson correlation and multiple regression analysis showed important finding. The relationship between organizational culture and E-commerce adoption significantly correlated with hotel performance. Meanwhile based on mediating model testing, the mediating effect of organizational culture in the hypothesized model exists. The findings of this study may be used to improve the method and management in Malaysia hotel industry environment and employees should be exposed to the requirement in the work culture towards globalization. Therefore, practice within the E-commerce adoption needs to consider the organizational culture as a key element in the hotel performance.

Keywords: organizational culture, E-commerce adoption, hotel performance

\section{Introduction}

The environment is getting more complex, business systems need to be more creative in order to identify new opportunities for sustained high performance. Organizations that run out to observe the tide of change will be left behind in many matters. This situation and demands force each organization to change, to abridge the gap in environmental changes that take place. At the close of the 20th century, E-commerce becomes more significant. In the 21st century, a market system that employs an electronic infrastructure has been supporting the world marketplace. Common Knowledge of information technology has no limits and anyone accessing the internet can make it (Laudon, 2009). Nevertheless, there is consensus that, the full potential of values brought about by E-commerce in Malaysia are unable to recognize.

It has been identified that lack of success stories by brick and mortar companies is a reason why traditional businesses are declining to initiate in E-commerce investments. Ainin and Noor Ismawati (2003) provide empirical support where 79 percent of the respondents cited "not many success stories of E-commerce" as the main barrier to Ecommerce adoption, followed by "not having knowledge in E-commerce" (72.6\%), "low internet access among buyers" (72.2\%), and "lack of knowledge on the potential of E-commerce" (69.6\%) in a study on E-commerce stimuli and practices among the small and medium enterprises (SMEs) in Malaysia. Ainin and Noor Ismawati (2003) provide empirical evidence, in which 79 percent of the respondents cited "not many success stories of E-commerce" as a major obstacle to the adoption of Electronic commerce, followed by "do not know Electronic Commerce" (72.6 \%), "Internet access among buyers are low" (72.2\%) and "lack of knowledge about the potential of E-commerce" (69.6\%) in a study of stimuli and practices of E-commerce among small and medium-sized enterprises (SMEs) in Malaysia.

The relationship between the effect of E-commerce adoption in the hotel performance in Malaysia are not so clear, although there are other studies in the west that shows the relationship between the E-commerce adoption with hotel performance exist by Rezvani (2011), Tow (2004), Amit and Zott (2001), and Uchitelle (2000) but is more focused on the manufacturing industry. A research in the tourism industry in general and especially the hotel sector, which looking for $\mathrm{E}$ commerce adoption impact on hotel performance in Malaysia is limited. While the tourism industry is the largest industry that uses information (Intan Salwani, et al., 2009; Norzaidi et al., 2007; Chow, 2000).

Changes in the organization because of influence from the external environment cannot be controlled and cannot 
be predicted easily, especially which associated with the technology, then the situation where different organizational cultures will have different internal effects are formed in an organization. This in turn will give a different effect on hotel performance (Gilaninia et al., 2012; Xiao, 2008; Mc Neese-Smith, 1993). The research by Xiao, (2009); Zammuto and O'connor, (1992); El Sawy, (1985), also support that organizational culture is a critical factor in the success of the use of information technology and thus make a profit from it. But in Malaysia, the research looking at organizational culture as a mediating factor between the E-commerce adoption, and hotel performance play an important role in the success of an information technology investment and E-commerce, and increases the hotel performance is limited. Therefore, this paper specifically examines the effects of E-commerce adoption on hotel performance, whilst treating organizational culture as a mediating variable. Malaysia hotel industry may used the finding of this this study to improve their method and environment management to exposed their employees to the requirement in the work culture towards globalization.

\section{Literature Review}

\subsection{Organizational Culture and E-commerce Adoption}

There is evidence that shows a case study of organizational culture is a factor in determining the ability of an organization to use information technology resources to improve business performance (Xiao, 2008; Serafeimidis and Smithson, 1999). At the same time, the adoption of organizational culture is a critical factor in getting profits from the information technology (Gilaninia et. al., 2011; Xiao, 2008; Zammuto and O'Connor, 1992, El Sawy, 1985). The study also questioned the use of E-commerce and organizations culture are complementary in influencing hotel performance. In order to achieve optimal business value of information technology, organizations need strength from the use of E-commerce and organizations culture in the new technological environment. In other words, the use of E-commerce without the support of culture does not give a lot to the ability of the organization.

\subsection{Organizational Culture and hotel performance}

One of the major topics in academic research and practical management is organizational culture, as a dimension of culture is central to all faces of organizational behavior (Fakhar Shahzad, 2012; Cascio, 2006; Alvesson, 2002). Several studies have been conducted over the last few decades related to this topic. According to Robbins and Sanghi (2007), Denison (1990), organizational culture is the principles, beliefs and values that are used as the basis for the organization's management system, which also is a set of behaviors and management practices where both as examples to reinforce these principles. The principles and practice continues to exist because it gives meaning to the members of an organization.

Writers use a variety of categories to describe what is meant by culture as a common behavior observed, group norms, values, philosophy, conditions, opinions, official ceremonies and celebrations (Schein, 2004). Although the description of the definition of culture has always been controversial, most authors generally agree on some general principles: 1. Culture is shared in a group 2. Culture is defined by the design of the values, beliefs and behavior-behavior 3. Cultures obtained through the development of social groups within a certain time period (Schein, 2004; Davidson and Martinsons, 2003).

Most researchers believe the ability of the organization is part of the organizational culture and contributions which have conducted several studies to strengthen the relationship between culture and business performance (Gilaninia et. Al., 2012; Vonderembse and Koufteros, 2004; Kendra and Taplin, 2004; Homburg and Pflesser, 2000, Kotter and Heskett, 1992; Denison and Mishra, 1995). According to Shahzad Fakhar (2012), a strong organizational culture can increase the income of the organization up to $765 \%$ between 1977 and 1988 and the state of organizational culture will affect the ability of the organization.

\subsection{E-commerce Adoption and Hotel Performance}

High dynamic and open information technology are the concept of E-commerce (Turban, 2008). E-commerce also known as run business without paper that comprise of messaging system, check, pay, and product delivery. The branch of this system are the exchange of electronic data, process communication (computer to computer applications) in the information business. Global electronic market system that consist of trading partners (sellers, buyers or middlemen) meets through the internet. Researchers have been highlighted several approaches and important role in explaining the E-commerce. Seven key roles in E-commerce had been identified by the majority of the researchers, that is, which can 
be found anywhere, global, consistent, density access, interactivity, information intensiveness, and 'Personalization' or 'Customization', (Laudon and Traver, 2012; Zhu and Kraemer, 2005; Turban, 2003).Xiao, (2008) defined hotel performance as firm's results or output that is measured by its intended outputs. Communication system that facilitated the flow of information rise the potential to increase sales by directly and immeditely reaching customers when a new product is introduced and by capitalizing the market that have been inaccessible due to distribution or other infrastructure (Wu et al., 2003). Synergies ensured by an integrated system when organizations can respond better to customer issues and request (Rogers et al., 1993).

Numerous studies and empirical research suggest that the ability of E-commerce not only increase productivity and efficiency, it also increases organization profit. "The resources that are unique to each organization, whether in history, with an accident, or mistake, and the diversity of resources explain the differences in the financial performance of the organization" (Peteraf, 1993). The ability of the entire organization is defined as profit organizations, economic rent arising from business activities (McGahan and Porter, 2002). An organization that possesses E-commerce benefit are likely to achieve above-normal profit (Rezvani et al., 2011). Productivity and economic construction are benefited from Ecommerce. Efficiency and cost effectiveness can be achieved through the high level of improvement in E-commerce efficiency of unit transaction and the low fixed costs of creating and retaining E-commerce (Wen, 2004). When the organization has implemented the E-commerce, internal improvements and higher levels of human resource growth, cost diminution, ongoing enhancement, and organizational efficiency can be achieved (Chang et. al., 2003). How to exploit the resources in creating and sustaining a competitive advantage for an organization that has become a focal point for marketing scholars that link different types of property based on market (Srivasta et. Al., 2001).

Figure 1 illustrated the foundation to propose a conceptual framework that used the theoretical and empirical evidence.

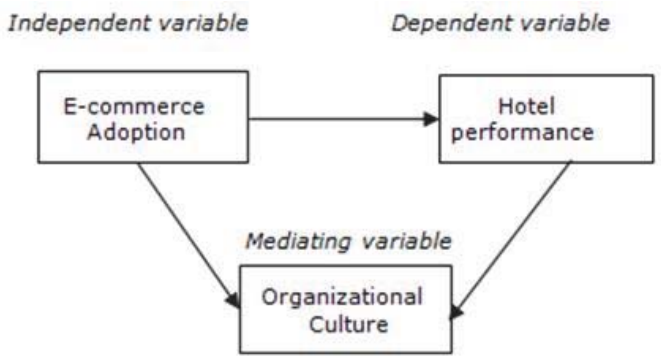

Figure 1: Conceptual framework

Established on the conceptual framework, it can be speculated that:

$\mathrm{H}_{1}$ : Organizational culture positively mediates the effect of E-Commerce adoption on hotel performance.

\section{Materials and Methods}

Three variables that are adopted from Tow (2004) and Li Xiao (2008), consisted in this review questionnaire are: a) Ecommerce adoption: 31 items, b) Hotel performance: 28 items, and c) Organization culture: 46 items. The acceptable standards for reliability analyses are the alpha croncbach greater than 0.60 , therefore all items chosen in this study had met the standards (Sekaran, 2003). All items in the questionnaire were applied 5 -item Likert scale ranging from " strongly disagree" (1) to "strongly agree" (5) as the measurement.

Malaysia hotel industries adopted E-commerce are the population of this study. An official approval had been obtained by the researchers to perform the study in the organization's management. In the use of cluster sampling, 146 review questionnaires had been distributed by the researchers to hotels below 3 stars and 111 review questionnaires to hotels above 4 star. The feedback rate from the questionnaire disseminated is 87 percent which is 226 questionnaires. But from the returned questionnaires, only 217 samples can be used which is 84 percent. Inferential statistics may be used to make analysis because the number of this sample exceeds the minimum sample of 30 participants as required by probability sampling techniques (Sekaran and Bougie, 2011).

A statistical Package for Social Science (SPSS) Version 20 were applying to analyze the data. The first step, to evaluate the efficacy and reliability of measurement scales, validity and reliability analyses were conducted (Nunally and Bernstein, 1994). Second steps, to determine the problem of collinearity, and to examine the relationship between the 
dependent variable and the independent variables, Pearson correlation analysis and descriptive statistics were performed (Hair et. Al., 2006). Pearson correlation analysis and descriptive statistics were performed to determine the collinearity problem, and to analyze the relationship between the variables. Lastly, to assess the magnitude and focal point at each independent variable, and distinct the mediating variable in the relationship between independent variable and dependent variable, multiple regression analysis was advocated (Baron and Kenny, 1986). Baron and Kenny (1986) indicate that a mediating variable can be considered in stepwise regression analysis when a previously significant effect of predictor variables is reduced to non-significance of reduced in terms of effect size after the inclusion of mediator variables into the analysis. Standardized coefficients (Standardized beta) were applied for all analyses.

\section{Results}

Table 1 depicts the result of reliability analysis for the measurement scales. In order to define the internet consistency of measurement scales, reliability analysis was guided for all research variables. Relying on Sekaran, (2003) guideline, this statistical analysis indicated that all research variables exceeded the acceptable standard at reliability analysis of 0.60 .

Table 1. Reliability analysis

\begin{tabular}{|l|c|c|}
\hline Measure & No. of time & Alpha Cronbach \\
\hline E-commerce adoption & 31 & 0.90 \\
\hline Organizational culture & 46 & 0.97 \\
\hline Hotel performance & 25 & 0.81 \\
\hline
\end{tabular}

Table 2 shows that the mean values of the variables are between 3.2 and 5.1. Meanwhile the findings of correlation analysis between E-commerce adoption and organizational culture $\left(0.280^{* *}\right)$, E-commerce adoption and hotel performance $\left(0.935^{\star \star}\right)$ and lastly between organizational culture with hotel performance $\left(0.489^{\star \star}\right)$.

Table 2. Pearson correlation analysis and descriptive statistic

\begin{tabular}{|l|c|c|c|c|c|}
\hline \multirow{2}{*}{ Measure } & \multirow{2}{*}{ Mean } & \multirow{2}{*}{ SD } & \multicolumn{4}{|c|}{ Pearson Correlation Analysis } \\
\cline { 4 - 6 } & & & $\mathbf{1}$ & $\mathbf{2}$ & $\mathbf{3}$ \\
\hline E-commerce adoption & 3.22 & 0.34 & $1-$ & - & \\
\hline Organizational culture & 3.18 & 0.53 & $0.280^{\star \star}$ & $1-$ & \\
\hline Hotel performance & 5.12 & 0.27 & $0.935^{\star \star}$ & $0.489^{\star \star}$ & 1 \\
\hline
\end{tabular}

Note: ${ }^{\star \star} p<0.01$

Shown in Table 3, Table 4, and Table 5 were the results of multiple regression analysis that were produced based on mediating model testing procedure as recommended by Baron and Kenny (1986).

Table 3 shows that $E$-commerce adoption significantly correlated with organizational culture $(B=28, p<0.01)$.

Table 3: The relationship between E-commerce adoption and organizational culture

\begin{tabular}{|l|c|}
\hline Independent Variable & Mediating variable (Organizational culture) \\
\hline E-commerce adoption & $0.28^{\star \star}$ \\
\hline R square & 0.078 \\
\hline Adjusted R square & 0.074 \\
\hline F & 18.3 \\
\hline
\end{tabular}

Note: ${ }^{\star \star} p<0.01$

E-commerce adoption significantly correlated with hotel performance as shown in Table $4\left(B=0.93^{\star \star}, p<0.01\right)$, showing that the important determinant of hotel performance is E-commerce adoption.

Table 4. The relationship between E-commerce application and business performance

\begin{tabular}{|l|c|}
\hline Independent Variable & Mediating variable (Organizational culture) \\
\hline E-commerce adoption & $0.93^{\star \star}$ \\
\hline R square & 0.87 \\
\hline Adjusted R square & 0.84 \\
\hline $\mathrm{F}$ & 1487.84 \\
\hline
\end{tabular}

Note: ${ }^{\star \star} p<0.01$ 
Organizational culture and E-commerce adoption have positive relationship and significantly correlated with hotel performance $(B=0.247, p<0.01)$ as shown in Table 5.

Table 5. The relationship between E-commerce adoption, organizational culture, and hotel performance

\begin{tabular}{|l|c|}
\hline Independent Variable & Dependent variable (Hotel performance) \\
\hline E-commerce adoption & $0.866^{\star \star}$ \\
\hline Organizational culture & $0.247^{\star \star}$ \\
\hline R square & 0.93 \\
\hline Adjusted R square & 0.924 \\
\hline F & 1418.27 \\
\hline
\end{tabular}

Note: ${ }^{* *} p<0.01$

\section{Discussion}

The results in Table 2 illustrated that, from correlation analysis, hotel performance have significant positive relationship with E-commerce adoption variable and organizational culture, this result supported by Rezvani et. Al., (2011). Meanwhile, based on model testing, three conditions should be meet by the hypothesized model to enable mediating effect of organizational culture exist: firstly, 1) the predictor variables are significantly correlated with the hypothesized mediator, second, 2) the predictor variables must affect the dependant variables in the second equation, and third, 3) a previously significant effect of predictor variables is reduced to non-significance or reduced in terms of effect size after the inclusions of mediator variables into the analysis. Therefore, hypothesis were fully supported. The previous significant effect of E-commerce adoption was reduced in terms of effect size after the inclusion of organizational culture into the analysis and this resullt is consistent with Baron and Kenny's (1986) mediating model testing condition. This finding justified that, between the relationship of E-commerce adoption and hotel performance, organizational culture does act as mediator.

This study gives major contributions in theoretical and practical. In terms of theoretical contribution, from the finding of this study, the effect of E-commerce adoption and hotel performanceis mediated by organizational culture. This result supports and extended studies by Tow (2004), and Xiao (2008). In terms of practical contribution, Malaysia hotel industry environment may used the findings of this study to improve the method and management. Management may achieved this objective when; firstly E-commerce adoption is exposed to all staff in hotel industries, and for the hotel that had adopted E-commerce, their employees need to have updated training content in order to improve their skills in Ecommerce adoption usage. Secondly, to provide an understanding and avoid employee anxiety, employees should expose to the requirement in the work culture towards globalization. Thirdly, in order to attract and motivate staff to commit with E-commerce adoption, learning activities need to be done.

\section{Conclusion}

The effect of E- commerce adoption on hotel performance in the studied organization had mediated by the organizational culture and this is confirmed from the outcomes of multiple regression analysis. This result has also supported by literature published in western countries. Therefore, organizational culture should be consider as the key element in the current research and practice of hotel performance within the E-commerce adoption. The conceptual and methodology limitations of this study can be the direction for further research in E-commerce. If the researcher considering following factors, further research in this area will be more attractice : firstly, performed a study that will compare the hotel that had adopt E-commerce with the hotel that still not adopt it. Secondly, the research involving the adopter of E-commerce hotel. Thirdly, the discovering of this study may create dissimilar effects if this study is performed in other industries in Malaysia.

\section{References}

Ainin, S., and Noor Ismawati, J. 2003. E-Commerce Stimuli And Practices In Malaysia. Proceedings Of 7th Pacifis Asia Conference On Information system (Pacis), Adelaide.

Alvesson, M. 2002. Understanding Organizational Culture. London. Sage publications.

Baron, R. M., and Kenny, D. A. 1986. The Moderator-mediator variable distinction in social psychological research: Conceptual, strategic, and statistical considerations. Journal of Personality \& Social Psychology, 51, 173-118.

Cascio, W.F. 2006. Managing Human Resources. Productivity, Quality of Life, Profits. City, McGraw-Hill Irwin.

Chang, Kuo-Chung, Jackson, J., and Grover, V. 2003. 'E-Commerce and corporate strategy: An executive perspective', Information and 
Management, vol. 40, pp. 663-675.

Chow, J. C. 2000. Comparison Of Improve \& Niosh Carbon Measurement. Paper presented at PM2000: Particulate Matter \& Health Conference Air \& Waste Management Association, Pittsburg, P.A.

Davidson, R., and Martinsons, M. G. 2003. Guest Editorial Cultural Issues and It Management : Past and Present. IEEE Transactions On Enginerring Management, 50(1), 3-7.

Denison, D. R. 1990. Corporate culture and organizational effectiveness: New York: Wiley.

Denison, D. R., and Mishra, A. K. 1995. Toward a theory of organizational culture and effectiveness. Organization Science 6(2), 204, 220.

El Sawy, O. A. 1985. Implementation by cultural infusion: An approach for managing the introduction of information technologies. MIS Quarterly, 9(2).131-110.

Fakhar Shahzad., Rana, A.L., Ayesha. R.L., and Lalarukh, S. (2012) Impact of Organizational Culture on Organizational Performance: An Overview Interdisciplinary Journal of Contemporary Research In Business, 3(9), 975-985.

Gilaninia, S.h., Omiidvani, N., Bakhshalipour, A., Eftekkhari, F., and Seighalani, F. Z. 2012. The Role of ICT in Performance of Small \& Medium Enterprise. Interdisciplinary Journal of Contemporary Research in Business. 3 (10).

Hair, J.F., Anderson, R.E., Tatham, R.L and Black, W.C. 1998. Multivariate Data Analysis. (5th edition), NJ: Prenctice Hall International, Inc.

Homburg, C., and Pflesser, C. 2000. A multiple-layer model of market-oriented organizational culture: Measurement issues and performance outcomes. Journal of Marketing Research, 37(4), 449-462.

Hussey, J., and Hussey, R. 1997. Business Research: A Practical Guide for Undergraduate and Postgraduate Students. Basingstoke, UK: McMillan Press.

Intan Salwani, M., Marthandan, G., Norzaidi, M.D., and Normah, O. 2008. E-commerce and value creation: empirical evidence in Malaysia. Proceedings of the European Applied Business Research Conference, Rothenburg,.

Kendra, K., and Taplin, L. J. 2004. Project success: A cultural framework. Project Management Journal. 35(1), 30, 16.

Kotter, J. P., and Heskett, J. L. 1992. Corporate culture and performance: New York: Free Press.

Laudon, K. and Traver. 2009. E-Commerce. New Jersey. Pearson Prentice Hall.

Laudon, K. and Traver. 2012. E-Commerce 2012 Coursemart. New Jersey. Prentice Hall.

McGahan A. M. (2002). What do We Know about Variance in Accounting Profitability? Management Science Vol. 48: 834-153.

Mc Neese-Smith, D. 1993. Leadership Behavior and Employee Effectiveness. Nurning Management; Chicago.

Norzaidi, M.D., Chong, S.C., Murali, R., and Intan Salwani, M. 2007. Internet usage and manager's performance in the port industry. Industrial Management \& Data Systems, 107 (8). 1227-50.

Nunally, J. C. 1978. Psycometric Theory (2nd Ed). New York: McGraw Hill Co. Inc.

Peteraf, M.A. 1993. 'The Cornerstones of Competitive Advantage: A Resource-based View', Strategic Management Journal, vol. 14, no. 3, pp. 179-91.

Rezvani, mousa, Gilaninia, Sh, and Mousavian, S.J. 2011. Strategic Planning: A Tool For Managing Organizations In Competitive Environments, Australian Journal of Basic and Applied Sciences, 5(9): pp1537-1546.

Robbins, S.P. and S. Sanghi. 2007. Organizational Behavior. Pearson Education, New Delhi.

Rogers, E.M. (1983). ' Diffusion of Innovations', 3rd ed., The Free Press, New York, NY,.

Sekaran, U., and Bougie, R. 2011. Research Methods for Business: A Skill Building Approach. UK: John Wiley \& Sons.

Schein, E. H. 2004. Organizational culture and leadership (3rd ed.): San Francisco: Jossey-Bass.

Srivasta R.K., and Christensen, H.K. 2001. 'The Resource-based View and Marketing: The Role of Market-based Asset in Gaining Competitive Advantage'. Journal of Management Vol. 27.

Tow, C.J. 2004. Development of E-commerce Capability Instrument Using The Resource-Based View Perspective And Its Application To Firm-Level Performance. Disertasi kedoktoran diterbitkan Proquest Digital Disertation, University of South Australia.

Turban, E., and King, D. 2003. Introduction to E-commerce, Prentice Hall, Upper Saddle River, NJ.

Turban, E. (2008). Electronic Commerce A Managerial Perspective 2008. Prentice Hall.

Uchitelle, L. , 2000. It's just the Beginning. New York Times, Special Section on E-commerce, June 7, p. E1.

Sekaran, U. and Bougie, R. 2011. Research Methods for Business: A Skill Building Approach. UK: John Wiley \& Sons.

Serafeimidis, V., and Smithson, S. 1999. Rethinking the approaches to information systems investment evaluation. Logistics Information Management, 12(1/2), 94.

Vonderembse, M. and Koufteros, X. 2004. The Impact Of Organizational Culture On Time Based Manufacturing \& Performance. Decision Sciences Journal, 35(4), (pp.579-607).

Wen, Mei. 2004. E-commerce, productivity, and fluctuation. Journal of Economic Behaviour and Organization 55: 187-206.

Wu, F., Mahajan, V., and Balasubramaniam, S. 2003. 'An analysis of e-business adoption and its impact on business performance', Journal of Academy of Marketing Science, vol. 31, no. 4 pp. 425-447.

Xiao L. 2008. The Impact Of Dynamic IT Capability And Organizational Culture On Firm Performance. Disertasi Kedoktoran diterbitkan Proquest Digital Disertation, The George Washington University.

Zammuto, R. F., and O'Connor, E. J. 1992. Gaining advanced manufacturing technologies' benefits: The roles of organization design and culture. Academy of Management Review, 17(4), 701-728.

Zhu, K., and Kraemer, K.L. 2005. Post-adoption variations in usage and value of e-business by organizations: cross-country evidence from the retail industry, Information Systems Research, 16 (1). 61-84. 